\section{Congressos, jornadas e feriados}

Com preocupante freqüência, observase que alguns eventos médicos, congressos e jornadas têm sido programados para épccas de feriados e dias santos.

Obviamente que não se pretende, com este artigo, cobrar de ninguém atitudes coerentes com princípios filosóficos ou religiosos. Afinal, espiritualidade e religiosidade são opções individuais que devem ser respeitadas. Contudo, quando se está à frente de alguma instituição comunitária, há que se respeitar as opções de todos, evitando-se situações que possam constranger a uns ou outros.

Considerando a cultura nitidamente cristã da sociedade brasileira, programar, por exemplo, algum tipo de festividade para uma Sexta-feira da Paixão, como já tive oportunidade de ver, chega a ser um enorme desrespeito ou um profundo desconhecimento do significado dessa celebração para os que crêem. Curiosamente até mesmo para os que não crêem, pois nesse dia, ainda que por superstição, muitos se mantêm num respeitoso recolhimento.

Fico pensando nos jovens médicos, ávidos em adquirir novos conhecimentos, enfrentando o conflito de participar ou não destes eventos... Por outro lado, há muito venho questionando por que os eventos científicos, quase sempre são programados para feriados civis ou dias santificados. A resposta que me dão é que assim não se perdem dias de serviço.

Mas, continuo refletindo: será que eu tenho tão pouco trabalho, ou trabalho tão pouco, ou ainda será que tenho pouca ou nenhuma ambição de ficar rico e famoso e por isso mesmo me permito viajar no meio de semana e fora de épocas tradicionais, se isso me interessar? Ou será que os outros têm tanto serviço que mal lhes sobra tempo para uma escapulida de três dias para um evento científico?

Um dos livros que mais me tocou pelo seu conteúdo, foi "Sobre a brevidade da vida", de Sêneca. Filósofo nascido na Espanha no ano I a.C. foi, em seu tempo, um dos homens mais influentes de Roma. Foi ele quem contestoua famosa frase de Hipócrates: "A vida é breve, longa, a arte" dizendo: "Não é curto o tempo que temos, mas dele muito perdemos". $\mathrm{E}$ completa: "não recebemos uma vida breve, mas a fazemos, nem somos dela carentes, mas esbanjadores." Numa de suas frases mais lapidares conclui: "Portanto, quando vires freqüentemente uma toga pretexta ou um nome célebre no fórum, não o invejes: essas coisas são adquiridas ao custo da vida." E mais à frente: "... após terem galgado o cume das honras, sobrevem o triste pensamento: "ter trabalhado tanto por uma inscrição num túmulo!"”

Não vou me alongar nas colocações de Sêneca. Mas deixo a sugestão para meus colegas mais esclarecidos: procurem e leiam esse livro, com muita atenção...

Mas, o meu questionamento é o seguinte: por que temos de "aproveitar" (êta palavra que me irrita!) um feriado prolongado para realizarmos nossos eventos científicos? Por que deixar a mulher (ou o marido) e os filhos num período que poderia ser desfrutado com eles num clube, num passeio, numa convivência maior que nosso trabalho nem sempre permite? Serão eles menos importantes do que nosso trabalho? Do que a Mercedes, 0 BMW ou a mansão com que muitos sonham?
Com certeza alguns responderão que viajam para os congressos com a família. Será que ela gosta? Ou a família estará passeando sozinha, enquanto o doutor participa das reuniões, aparece bastante para os colegas (para que?...) e acumula certificados para pendurar nas paredes do consultório?

O ócio - palavrinha detestada sobretudo pelos trabalho-dependentes - é vital para o ser humano. Quem consegue equilibrar o ócio com o trabalho é aquele que realmente é feliz. Vive feliz, não teme a morte, morre feliz. Volto a Sêneca: "Devese aprender a viver por toda a vida e, por mais que tu talvez te espantes, a vida toda é um aprender a morrer."

Portanto, tenho a firme convicção que congressos e jornadas devem ser feitos em dias "úteis". Os feriados ficam para um justo ócio com a família. Os dias santos, para os que acreditam, serão ocasiões para uma meditação sobre a vida e a morte; para os que não acreditam, mais um tempo para se dedicar melhor à família.

Quem sabe é exatamente por não se fazer isso, que andamos tão falsamente felizes, exibindo sorrisos, carrões e roupas de etiqueta muletas para a nossa real infelicidade? Quem sabe não é por isso que tantos casamentos se acabaram? Tantos filhos se envolveram com as drogas?

Mas nunca é tarde para uma reflexão, para uma radical mudança de vida. Afinal, caixão não tem gaveta, só alças para os nossos amigos nos conduzirem mais depressa para a sepultura. E se quisermos, hoje pode ser o primeiro dia da vida que ainda teremos!

Evaldo A. D'Assumpção 